\title{
Too much, too fast? The Sources of Banks' Opposition to European Banking Structural Reforms
}

Citation for published version (APA):

Spendzharova, A., Versluis, E., Flöthe, L., \& Radulova, E. (2016). Too much, too fast? The Sources of Banks' Opposition to European Banking Structural Reforms. Journal of Banking Regulation, 17(1-2), 133145. https://doi.org/10.1057/jbr.2015.16

Document status and date:

Published: 01/03/2016

DOI:

10.1057/jbr.2015.16

Document Version:

Accepted author manuscript (Peer reviewed / editorial board version)

Document license:

CC BY-NC-ND

\section{Please check the document version of this publication:}

- A submitted manuscript is the version of the article upon submission and before peer-review. There can be important differences between the submitted version and the official published version of record.

People interested in the research are advised to contact the author for the final version of the publication, or visit the DOI to the publisher's website.

- The final author version and the galley proof are versions of the publication after peer review.

- The final published version features the final layout of the paper including the volume, issue and page numbers.

Link to publication

\footnotetext{
General rights rights.

- You may freely distribute the URL identifying the publication in the public portal. please follow below link for the End User Agreement:

www.umlib.nl/taverne-license

Take down policy

If you believe that this document breaches copyright please contact us at:

repository@maastrichtuniversity.nl

providing details and we will investigate your claim.
}

Copyright and moral rights for the publications made accessible in the public portal are retained by the authors and/or other copyright owners and it is a condition of accessing publications that users recognise and abide by the legal requirements associated with these

- Users may download and print one copy of any publication from the public portal for the purpose of private study or research.

- You may not further distribute the material or use it for any profit-making activity or commercial gain

If the publication is distributed under the terms of Article $25 \mathrm{fa}$ of the Dutch Copyright Act, indicated by the "Taverne" license above, 


\title{
Original Article
}

\section{Too much, too fast? The sources of banks' opposition to European banking structural reforms}

\begin{abstract}
Aneta Spendzharova
is Assistant Professor in the Political Science Department of Maastricht University. She is interested in the politics of European banking supervision, regulatory governance, and banking sector developments in Central and Eastern Europe. Her research has been published in journals such as Review of International Political Economy, Journal of European Public Policy, Journal of Common Market Studies, and West European Politics.
\end{abstract}

\section{Esther Versluis}

is Professor of European Regulatory Governance at Maastricht University. Her research interests are in the areas of regulatory governance, policy analysis, policy implementation, agencies, and risk governance. Her work has been published in journals such as Journal of European Public Policy, Journal of Common Market Studies, West European Politics, European Journal of Risk Regulation and Journal of Hazardous Materials.

\section{Elissaveta Radulova}

is Assistant Professor in the Political Science Department of Maastricht University. Her research interests are in the areas of policy implementation, policy framing analysis, EU employment and higher education policies. Her work has been published in journals such as Journal of European Integration and the European Integration Online Papers.

\section{Linda Flöthe}

graduated from the Research Master's European Studies at Maastricht University. Currently, she is a graduate student at Leiden University conducting research within the project 'When does Government listen to the Public?' (GovLis). Her research interests are in the areas of European agencies, regulatory governance and interest groups.

Correspondence: Aneta Spendzharova, Department of Political Science, Maastricht University, P.O. Box 616, 6200 MD Maastricht, The Netherlands

E-mail: a.spendzharova @ maastrichtuniversity.nl

ABSTRACT This article examines banks' positions on the 2014 proposals for EU banking structural reforms. Centralization of authority in banking regulation and supervision has been a legislative priority in the European Union (EU) since 2008 in order to address regulatory shortcomings in the aftermath of the global finanical crisis. European decision makers have introduced more stringent capital adequacy requirements and transferred greater powers to the European Supervisory Authorites. In 2014, the European Commission put forward a proposal for banking structural reforms comprised of two elements: a ban on proprietary trading and mandatory separation of some trading activities from the deposit-taking entity. We refer to 'regulatory cascading' in order to conceptualize the rapid and successive introduction of legislative packages designed to fix problems and gaps in the EU banking regulatory framework. Our analysis shows that the majority of European banks and financial services associations are opposed to further banking structural reforms at the EU level. We find evidence that banks domiciled in member states that have already passed reforms prefer those over EU alternatives. Large internationalized banks are most opposed to further EU banking structural reforms.

Journal of Banking Regulation advance online publication, 20 January 2016; doi:10.1057/jbr.2015.16 
Keywords: EU banking structural reforms; Liikanen report; ring fencing; ban on proprietary trading; EU banking industry

\section{INTRODUCTION}

The 2008 global financial crisis revealed that the de-regulation agenda of the 1980s and 1990s in jurisdictions hosting leading financial centers such as the United States (US) and United Kingdom (UK) undermined financial stability. ${ }^{1}$ Financial sector firms developed innovative products but failed to introduce a matching array of robust risk management practices. Since 2009, European governments have introduced a series of reforms to ensure more hands-on supervision, careful monitoring of systemic risks, and higher capital adequacy of banks. ${ }^{2}$ At the same time, the rapid institutional innovation and reforms in banking, both at the global and European level, have given rise to compliance and implementation challenges for the financial industry. Increasingly, policymakers conduct extensive regulatory impact assessments before rolling out new legislation, but their capacity to anticipate the consequences of regulatory changes remains bounded. ${ }^{3}$ In particular, policymakers rarely have a full overview of the interaction between the new rules and their cumulative impact on the regulated industry.

Immediately after 2008, reining in the financial industry dominated the global and European political debates. Centralization of authority in banking regulation and supervision became a key legislative priority in the EU in order to fix the regulatory shortcomings. ${ }^{4}$ European decision makers transferred greater powers to the European Supervisory Authorites in banking, securities, and insurance; introduced more stringent capital adequacy requirements; and set out to create a European Banking Union. $^{5}$ By 2015, however, concerns about the unintended consequences of overregulation have come to the fore. In 2014, Frans Timmermans, the newly appointed First Vice-President of the European Commission, received the 'better regulation' portfolio and a broad mandate to reduce the administrative burden of European legislation on business, the public sector, and consumers. ${ }^{6}$

In this article, we examine banking structural reforms at the EU level against the backdrop of similar legislation put forward at the global and domestic level. The European Commission's 2014 legislative proposal contains two main elements: a ban on proprietary trading and mandatory separation of some trading activities from the deposit-taking entity. Earlier EU legislation, such as the Capital Requirements Directive IV and the Single Supervisory Mechanism Regulation, offered large internationalized banks the advantages of a European level playing field, single supervisory contact point, and a single rulebook in banking. ${ }^{7}$ By contrast, the most tangible consequences of the proposed EU banking structural reforms are higher compliance costs and significant restructuring of banks' business operations.

Hence, European banks and financial industry associations have expressed opposition to EU-level banking structural reforms. ${ }^{8}$ The key independent variables in our analysis of the sources of this opposition are existing domestic legislation in the area of banking structural reform, bank size and degree of internationalization. The selected issue area allows us to unpack the complex interaction of global, (macro-)regional, and national regulatory changes introduced in the aftermath of the 2008 global financial crisis. We refer to 'regulatory cascading' in order to conceptualize the rapid successive introduction of legislative packages designed to address problems and gaps in the EU banking regulatory framework.

In the following sections, we first take stock of the proposed EU banking structural reforms against the backdrop of similar global initiatives. Next, we present two propositions to account for the observed variation in stakeholders' positions, focusing on banks and financial industry associations. After that, we analyze the 
preferences expressed in the stakeholder consultation submissions. The last section summarizes the main findings of our analysis.

\section{EUROPEAN BANKING STRUCTURAL REFORMS IN A GLOBAL PERSPECTIVE}

The US and UK have led the international efforts to re-structure the banking sector and make systemically important banks more resilient in the aftermath of the 2008 global financial crisis. Both states are home to global, systemically important banks (G-SIBs) as well as host to substantial operations of foreign G-SIBs. The US adopted reforms such as the Volcker Rule, the Swaps Push-Out Rule, and the Foreign Banking Organizations Rule as early as 2010 . $^{9}$ The UK has spearheaded regulatory efforts in Europe. The 2013 Financial Services (Banking Reform) Act implemented the recommendations of the Independent Commission on Banking, the so-called 'Vickers Report' (FTI Consulting $^{10}$, p. 2). These measures were designed to reduce risks to the deposit-taking parts of banking groups stemming from trading activities and limit the implicit public guarantees for banks. Moreover, policymakers aimed to simplify the legal and operational structures of complex banking entities in order to make it easier to supervise and resolve the groups. Eventually, the desired effect of the reforms would be to reduce systemic risk, enhance depositor protection, and limit the need for state-led bailouts. ${ }^{11}$

At the global level, the G20 has been actively engaged in coordinating the effort to harmonize the measures adopted in different jurisdictions. In 2013, the G20 called on the Basel-based Financial Stability Board (FSB) to take stock of the ongoing banking structural reforms. The regulatory changes identified by the FSB fell in four categories: ${ }^{11}$

1. Require ring-fencing of deposit-taking activities and/or separation of specific activities into different legal entities;
2. introduce bank activity restrictions such as bans on proprietary trading;

3 . introduce or materially strengthen requirements related to capital, intra-group exposure limits, liquidity, funding sources to parts of a banking organization on a sub-consolidated basis;

4. require or incentivize banks to operate through certain structures rather than others, for example, subsidiaries rather than branches.

While US and UK lawmakers moved quickly with the introduction of banking structural reforms, progress in the EU has been slow. At the time of writing, the European Parliament and Council were considering the Commission's 2014 proposal for a Regulation on Banking Structural Reform for the entire EU. ${ }^{12}$ It consists of two elements: first, a ban on proprietary trading and, second, measures to separate select trading activities from the deposit-taking entity. The Commission proposed common EU legislation on banking structural reform despite existing individual country measures in order to ensure a coherent European approach. Its assessment hihglights a number of anticipated benefits for the EU's single market, such as 'uniform rules on banks', structures that would enhance financial stability within the EU, better integrate financial markets, facilitate the orderly resolution and recovery of the group, enhance the cross-border provision of services, reduce competitive distortions, and prevent regulatory arbitrage. ${ }^{12}$ The EU legislation in banking structural reform is shaped by the recommendations of the 2012 Liikanen Report, prepared by the High-level Expert Group on structural bank reforms. ${ }^{13}$

Analysts have highlighted the different approaches to banking structural reform taken in the US and the EU. The broader US focus has been on removing investment-banking activities altogether from commercial banks and affiliates, while the European focus has been on the separation of retail and investment banking by ring-fencing through the use of 
subsidiaries, mainly in order to mitigate the risks related to bank failure (FTI Consulting ${ }^{10}$, p. 3 ). While the US has enacted stricter prohibitions on proprietary trading for all banks, in the EU there is no ban on proprietary trading outside of the ring-fenced entities. Also, the scope is narrower under the European proposals. For example, the UK ring-fencing reforms apply rules exclusively to domestic retail banking. The latest EU proposals are conceptually similar to ring-fencing in the UK, as they include the mandatory separation of trading entities from deposit-taking entities within a group and the additional separation of other activities if deemed necessary by the authorities in light of the institution's recovery and resolution plan (FTI Consulting $^{10}$, p. 3). At the same time, a US-style ban on proprietary trading is also envisioned in the EU reforms, but it will not apply outside the ring-fenced deposit-taking bank entity. ${ }^{14}$

The proposed banking structural reforms at the EU level will have significant repercussions for banks operating across the union. First, the ban on proprietary trading would entail restricting the range of financial instruments that banks may trade. The main objective of the legislation is to reduce the systemic risk associated with the largest, most complex, and interconnected banks. ${ }^{11}$ This will affect trading in order to make a profit for the bank's own account, without any connection to client activity, the hedging of the bank's risk, or for cash management purposes. Just as under the Volcker Rule in the US, trading in EU sovereign debt instruments would be excluded from any restrictions on proprietary trading.

Second, mandatory separation would require that the deposit-taking entity and other entities be fully distinct in legal, economic, governance and operational terms. Once adopted, the reforms would apply in all 28 EU member states. The rules cover EU-based banks as well as EU branches and subsidiaries of non-EU banks. This proposal also aims to facilitate the effective and timely resolution of the largest and most complex banks. Risky activities would be located in separate legal entities, insulated from the core deposit-taking business. The legislation will affect directly the activities and structure of EU banks identified as being of global systemic importance and/or banks exceeding certain thresholds such as $€ 30$ billion in total assets and trading activities either exceeding $€ 70$ billion or 10 per cent of the bank's total assets. ${ }^{12}$

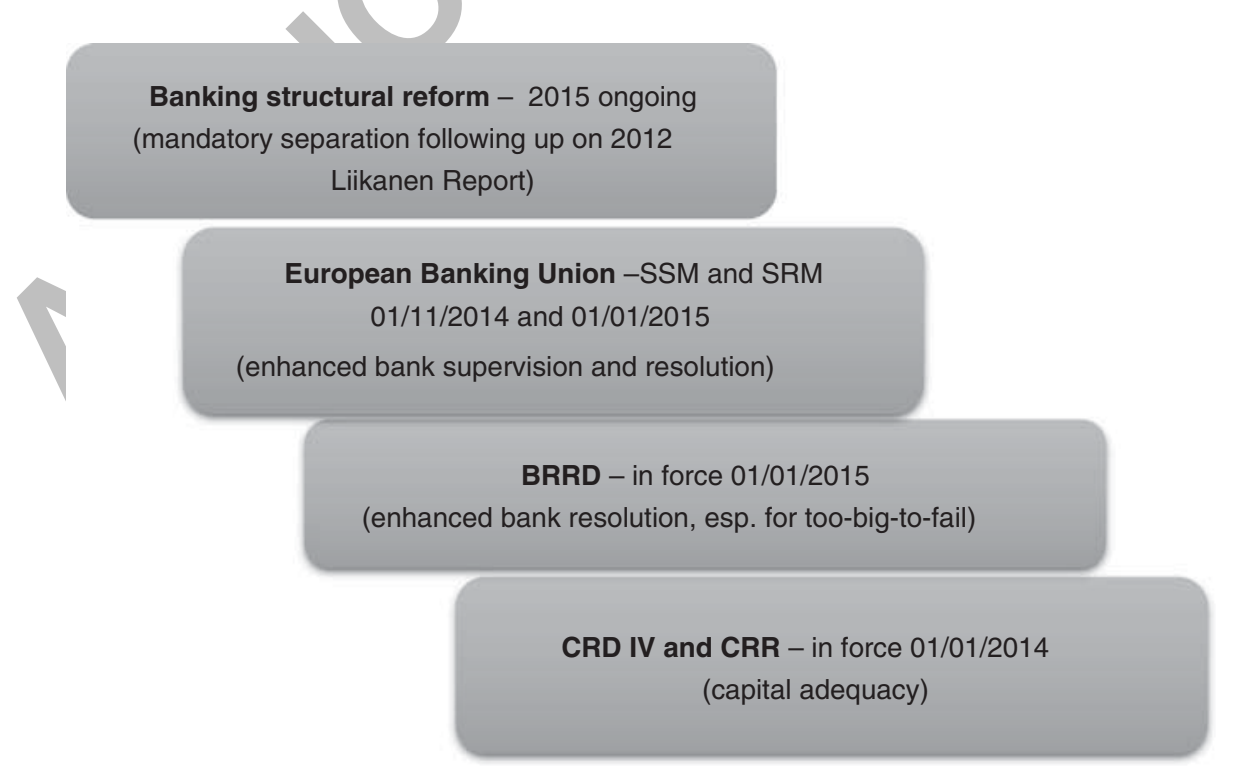

Figure 1: Regulatory cascading in banking structural reform in the EU. 


\section{REGULATORY CASCADING IN EUROPEAN BANKING SECTOR REFORMS}

If adopted, the proposed ban on proprietary trading and mandatory separation of deposittaking from investment-banking activities would add another layer of institutional reform to already existing EU legislative measures in the realm of capital adequacy, deposit guarantee schemes, and bank resolution. To illustrate the regulatory cascading observed at the European level, Figure 1 summarizes the timing and purpose of major legislative packages such as CRD IV, CRR, BRRD, SSM, SRM and the 2012 Liikanen Report that set the parameters for banking structural reform in the EU.

Overall, European banking structural reforms will have an impact on the trading practices and operational structure of large internationalized European banks, such as UK-based HSBC, Barclays, and RBS; France-based BNP Paribas; Germany-based Deutsche Bank and Commerzbank; Spain-based Banco Santander and BBVA; Netherlands-based ING; and Italybased UniCredit and Intesa Sanpaolo. ${ }^{15}$ The measures will affect not only large global and regional banks but also smaller cooperative banks relying heavily on deposit taking such as France-based Confédération Nationale du Crédit Mutuel; Germany-based Bundesverband der Deutschen Volksbanken und Raiffeisenbanken; and Austria-based Raiffeisenbank.

A study conducted by Pricewaterhouse Coopers for the Association for Financial Markets in Europe finds that up to 9 of 18 systemically important banks in the region might shut down their interest rates, commodities, and securitization activities because returns would be hit by the proposed banking structural reforms. ${ }^{16}$ Considering the significant impact of the changes on banks' business models, it is not surprising that the EU legislative proposals have been met with an unprecedented amount of resistance from member states hosting most of Europe's largest banks as well as banking sector associations. Officials from five of the countries that are most skeptical about the value added of EU-level banking structural reforms, France, the UK, Germany, Sweden and the Netherlands, met in Riga in January 2015 to discuss whether a common European approach is necessary. ${ }^{17}$ At the same time, banks have been actively lobbying the EU's Financial Services Commissioner, Jonathan Hill, to abandon the structural overhaul of the EU banking system altogether. ${ }^{18}$

\section{EXPLAINING BANKS' OPPOSITION TO STRUCTURAL REFORMS AT THE EUROPEAN LEVEL}

To understand why the European banking sector is vehemently opposed to further structural reforms at the European level, we analyze the Commission's stakeholder consultation on 'Reforming the structure of the EU banking sector', conducted in 2013. ${ }^{19}$ In particular, we investigate the factors shaping the extent of a bank's opposition to further banking structural reforms in the EU. A growing body of literature has shown that stakeholder consultations provide valuable insights into the positions of business actors, consumer organizations, and NGOs on European legislation. ${ }^{20}$ In terms of the format used, ${ }^{21}$ the Commission conducted a standardized online open consulation. It presented stakeholders with a list of closed-ended questions. Any interested parties could then submit a position and explain their reasoning about the outlined questions.

Using qualitative content analysis, ${ }^{22}$ we coded the submitted positions on a $1-5$ scale, where 1 indicates a favorable stance on further EU banking structural reforms and 5 indicates strong opposition to such changes. This is the dependent variable in our analysis - position on further EU banking structural reforms. Taking into account the full sample of 47 stakeholder statements issued by banks, financial industry groups, and NGOs, we find that consumer organizations and NGOs are the most vocal 
and ardent supporters of further banking structural reforms in the EU. By contrast, most industry actors such as banks and financial sector associations are opposed to additional structural reforms at the EU level. Nevertheless, even among the groups opposing further structural reforms, some actors are willing to accept some changes while others dismiss any additional reforms as an unnecessary regulatory burden. How can we explain variation in the positions of banks and financial industry groups? We put forward two propositions to account for the observed differences.

Proposition 1: Banks domiciled in jurisdictions that have implemented domestic banking structural reforms prefer those over other EU alternatives.

We expect that banks domiciled in a jurisdiction that has already adopted banking structural reforms will express a preference to have these 'uploaded' on the EU level. Both the historical institutionalist mechanism of path dependence and the rational choice mechanism of adjustment costs would lead us to anticipate that banks domiciled in jurisdictions that have implemented domestic banking structural reforms would prefer the domestic status quo over other EU alternatives. Path dependence is often induced by earlier policy choices through positive feedback effects. ${ }^{23}$ When banks adopt a national regulatory regime, they put in place internal rules to ensure compliance. Organizationally, 'the path of least resistance' for banks is to stick to the standard operating procedures that have been put in place. Moreover, following the logic of rational choice institutionalism, the additional financial costs of complying with a different regulatory regime would also compel banks to choose the national status quo over other EU alternatives.

Several EU member states such as the UK, France, and Germany have already put in place domestic banking structural reforms before any common EU plan had been developed. Following our first proposition, we would expect banks domiciled in the UK, France, and
Germany to express a preference for the type of reform introduced in the home jurisdiction. To begin with, the UK has introduced two key structural banking reforms: the so-called ringfencing of core banking activities and a new authorization procedure for UK branches of non-EEA banks. ${ }^{24}$ Drawing on the recommendations of the 2011 Vickers Report, this legislative act requires a UK bank's retail deposits, overdrafts, and associated payments services to be placed in a subsidiary, also referred to as a 'ring-fenced body', which in turn is prohibited from engaging in a range of investment banking activities. ${ }^{25}$ The main objective of ring fencing is to insulate the provision of core banking services from what are perceived as riskier investment activities.

Apart from the UK, France and Germany have also adopted domestic banking structural reforms, largely following the recommendations of the 2012 Liikanen report. These measures aim to preserve financial stability and protect deposits and retail banking against risks arising from certain trading activities. In both states, if a deposit-taking credit institution, or an entity that belongs to a group that includes a deposit-taking credit institution, exceeds certain thresholds, it must either discontinue certain trading activities or transfer those activities to a trading entity which is economically, operationally, and legally separated from the deposit-taking credit institution. ${ }^{26}$

Under the French and German reforms, the activities that need to be structurally separated from core deposit-taking operations are proprietary trading and certain relations with hedge funds. ${ }^{10}$ Proprietary trading is defined as an acquisition and sale of financial instruments on the institution's account, without a service for third parties, except when used for prudent hedging and management of the institution's capital. At the same time, market-making, which is considered as a key activity for the financing of the economy, is still allowed within the deposit-taking credit institution. ${ }^{26}$ This is seen as a measure preserving the universal banking model, which is wide-spread in the EU. 
Proposition 2: Large internationalized banks are most opposed to further banking structural reforms at the EU level.

We expect that the business model of a bank or financial group will influence its position on the desirability of banking structural reform in the EU. In particular, if the bank perceives the effect of regulatory reform to be detrimental and costly, we would expect a negative position on the proposed legislation. Large internationalized banks have supported recent harmonization measures in EU banking supervision such as introducing a single rulebook. ${ }^{27}$ Yet, the evidence so far suggests that they are very skeptical about the value added of banking structural reforms at the EU level, despite the arguments of reform advocates such as the European Commission and the European Central Bank (ECB). For example, Vitor Constâncio, a member of the ECB's Executive Board, has warned that a 'patchwork of inconsistent national frameworks would increase financial fragmentation across the single market and carry a risk of regulatory arbitrage. ${ }^{17}$ Nevertheless, industry associations have focused on defending national reform initiatives and criticizing the European proposals. In a joint letter to EU Commissioner Frans Timmermans, the British Bankers' Association and the French Banking Federation have argued that the EU initiative is outdated, harmful to capital markets and complicates the implementation of existing national laws, such as the UK's Vickers reforms introducing ring fencing and the structural reforms implemented in France. ${ }^{18}$

With that said, we need to take into account that EU banking structural reforms will affect not only large internationalized banks but also smaller cooperative banks. Mandatory separation measures will undermine their so-called 'inverted pyramid' structure of co-operative networks, where local co-operative banks jointly own the central bank institutions. One of the main functions of a cooperative central bank is to secure the liquidity and refinance the regional cooperative banks and its subsidiaries. The industry associations of cooperative banks have argued that a separation of trading activities would limit the nationwide supply of adequate credits and financial products to SMEs and private clients. ${ }^{28}$ In addition, it would lead to a rise in funding and liquidity cost for the regional cooperative bank. Overall, we expect smaller cooperative banks to express a preference for national discretion in the implementation of any EU-level banking structural reforms and exemptions for banks with smaller balance sheets. However, in our sample, these actors express their preferences through EU-level industry associations such as the European Association of Co-operative Banks (EACB), European Association of Public Banks, and European Savings Banks Group rather than as individual entities.

\section{ANALYZING THE STAKEHOLDER POSITIONS}

Consumer associations such as the Federation of German Consumer Organizations and Portuguese Consumer Association are by far the most ardent supporters of further banking structural reforms at the European level. We summarize the rationale for supporting further reforms presented by consumer organizations before unpacking the sources of banks' opposition to additional banking structural reforms. For example, the Swedish Association for Bank Customer Rights, established in response to Sweden's banking crisis in 1987-1993, prefers a EU-level legislative initiative to ensure full bank separation, as 'without a full bank separation the deposits on the bank accounts of the European SMEs and depositors are endangered. ${ }^{29}$ Similarly, the European Financial Services User Group expresses full support for the separation of Europe's largest and most complex banks. According to the association, the reform of the EU banking sector 'should aim for the elimination of taxpayers' liability, excessive risk-taking, and the stake that taxpayers have in the trading parts of banking groups' $\left(\mathrm{FSUG}^{30}\right.$, p. 3). The group emphasizes that EU reforms need to go further than the ringfencing measures adopted in the UK, for example, and urges to 'electrify' the ring fencing of 
commercial banking activities by more stringent bank separation legislation that applies to all banks active in the EU (FSUG ${ }^{30}$, p. 4).

A few banks have also expressed support for the proposed mandatory separation of deposittaking and investment activities. For instance, Spain-based Banco Popular, the Italian Banking Association, and Spain-based la Caixa Goup all signal support for further banking structural reforms. La Caixa acknowledges the risk of over-regulation, but maintains that 'the separation of highly risky activities -mainly proprietary trading - would increase the resilience of the banking system and reduce the distortions that arise from cross-subsidization between depositors and other activities. ${ }^{31}$

The opponents of further banking structural reforms at the EU level include large international and regional banks such as Deutsche Bank, UniCredit, Standard Chartered, RBS Group, Nordea and SEB. At the same time, associations representing public banks and cooperative banks also express opposition to further structural reforms. Let us probe more carefully the factors driving the extent of opposition to further EU reforms, referring to propositions 1 and 2 .

According to proposition 1, we expect banks domiciled in jurisdictions that have implemented domestic banking structural reforms to prefer those over other European alternatives. As shown in Table 1 , the positions of banks based in the UK, Germany, and France are in line with this expectation. Although they express different intensity of opposition to EU structural reforms, four of the five UK-based actors in the sample, Barclays Bank, the British Bankers' Association, RBS and Standard Chartered, signal that they will accept the ring fencing of core banking activities. This is in line with the domestic measures implemented by the UK government discussed earlier in the article. Similarly, Germany-based banks and associations stress that the German legal framework provides significant safeguards for financial stability. Two out of three France-based actors in the sample, Crédit Agricole and the
French Banking Association, express a preference for the French domestic status quo. Crédit Agricole explicitly emphasizes that the European framework 'should be based on the main principles underlying the French and German banking reforms laws. ${ }^{32}$ An additional finding of our analysis is that Spanish banks are located on the opposite end of the spectrum and express a strong preference for further European banking structural reforms. At the same time, the small number of submissions in the stakeholder consultation warrants caution when we generalize these findings to the entire domestic banking sector in the EU member states.

According to proposition 2, we expect large internationalized banks to be most opposed to further European banking structural reforms. To test this proposition we conducted a difference of means test. We checked whether there is a statistically significant difference in the average score on acceptance of or opposition to European banking structural reforms among three distinct groups of actors in the stakeholder consultation. The independent variable in this case, type of actor, has three levels: large internationalized banks (including both global and regional banks); banking associations; consumer organizations and non-governmental organizations (NGOs). Table 2 reports the descriptive statistics for the independent variable. The anova analysis was significant. Thus, we can reject the null proposition there is no difference in the mean scores of the three groups of actors. As shown in Table 3, we established statistically significant pair-wise differences among several groups. Both large internationalized banks and banking associations have a

Table 1: Banks' positions on EU banking structural reforms, domestic status quo v. further European reforms

\begin{tabular}{lccc}
\hline $\begin{array}{l}\text { EU } \\
\text { member } \\
\text { state }\end{array}$ & $\begin{array}{c}\text { Number of banks } \\
\text { in stakeholder } \\
\text { consultation }\end{array}$ & $\begin{array}{c}\text { Preference for } \\
\text { domestic } \\
\text { status quo }\end{array}$ & $\begin{array}{c}\text { Preference for } \\
\text { more European } \\
\text { reforms }\end{array}$ \\
\hline UK & 5 & $4(80 \%)$ & - \\
France & 3 & $2(67 \%)$ & - \\
Germany & 2 & $1(50 \%)$ & - \\
Spain & 2 & - & $2(100 \%)$ \\
\hline
\end{tabular}


significantly higher level of opposition to EU banking structural reforms compared to consumer organizations and NGOs. However, the pair-wise comparison of large internationalized banks' and banking associations' mean scores is not statistically significant. Both types of actors are rather opposed to further EU level reforms.

The stakeholder consultation positions confirm significant opposition to EU banking structural reforms, especially from large internationalized banks. The analysis showed that banking sector associations are also rather opposed to further reforms. Let us consider in greater detail the arguments presented by financial sector actors. Denmark-based Danske Bank also argues that mandatory separation of deposit-taking and investment activities would undermine financial stability by removing the diversification benefits inherent in the universal banking model. ${ }^{33}$ Instead of an across-theboard mandatory separation in the EU, the bank favors harmonized effective resolution plans, clear bail-in mechanisms, and thorough, appropriate limits on risk taking in investment banking. It also points out that these goals are addressed through existing EU legislation such as BRRD and SRM. Similarly, the position of UK-based RBS shows concern that mandatory EU-wide structural reforms may be detrimental. RBS warns that 'such measures might serve to concentrate risk by undermining the diversity of European banks that have arisen to serve customers' needs. ${ }^{34}$

The German Banking Industry Committee (GBIC) is a forum that brings together the central associations of the German banking industry, representing over 2000 private commercial banks, cooperative banks, public-sector banks and savings banks. Its position highlights the importance of diversity of national banking structures across the EU for the stability and resilience of the European banking system. The committee points out that structural separation would lead to a concentration of risks in uniform business models, which goes against the goal of the legislative package. GBIC also emphasizes the importance of the universal banks model in Europe, which would be jeopardized under broad ex-ante separation and argues that, when done responsibly, mixing funding from deposits and the capital market benefits the banking business as a whole (German Banking Industry Committee ${ }^{35}$, p. 3).

\section{Managing regulatory cascading}

So far, we have seen that banks domiciled in jurisdictions that have passed reforms prefer

Table 2: Position on EU banking structural reforms, descriptive statistics

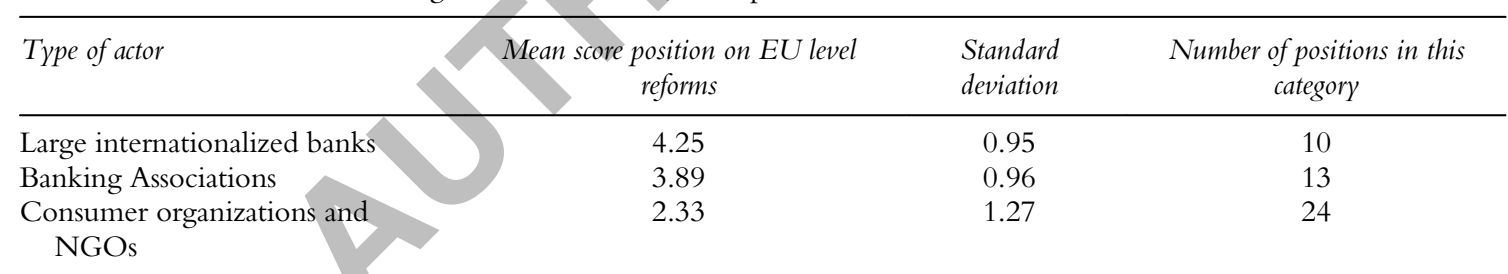

Note: The positions were coded on a 1-5 scale, where 1 indicates a favorable stance on further EU banking structural reforms and 5 indicates strong opposition to such changes.

Table 3: Position on EU banking structural reforms, pair-wise comparisons

\begin{tabular}{lccc}
\hline \multicolumn{1}{c}{ Type of actor } & Difference of means & Standard error & Significance \\
\hline Large internationalized banks v. Banking Associations & 0.366 & 0.475 & 0.446 \\
Banking Associations v. Consumer organizations and NGOs & $1.551^{\star}$ & 0.389 & 0.000 \\
Consumer organizations and NGOs v. Large internationalized banks & $-1.917^{\star}$ & 0.425 & 0.000 \\
\hline
\end{tabular}

Note: ${ }^{\star}$ indicates statistically significant difference of means between the two groups, $P<0.05$. 
those over EU alternatives and large internationalized banks are most opposed to further EU banking structural reforms. In addition, the stakeholder positions offer evidence that European banks are concerned about the perceived growing regulatory burden of EU legislation. Of all 47 positions, 21 (44, 7 per cent) express some concern about the cumulative effect of EU regulations imposed in addition to national and global ones. Clearly, this is an important issue brought up by the European banking sector, taking into account that the format of the stakeholder consultation is a structured questionnaire and regulatory cascading was not explicitly mentioned among the topics. ${ }^{36}$

How do banks and financial sector association substantiate these concerns? For example, the German Banking Industry Committee underscores that preceding EU legislative packages such as CRD IV, CRR, and BRRD have 'tightened capital and risk management requirements, granted supervisors more powers or are planning to do so, and initiated a reasonable solution to the problem of banks becoming too big to fail' (German Banking Industry Committee $^{35}$, p. 2). Furthermore, the committee takes issue with the reasoning for banking structural reform, arguing that there is no evidence that structural separation reduces complexity and the likelihood of banking crises. It stresses that 'separating risks by transferring trading exposure onto one entity and credit risk onto another has no bearing on the financial system's aggregate exposure. Even after a separation, a complex and risky transaction remains just that' (German Banking Industry Committee $^{35}$, p. 3). We see similar concerns in the individual position of Deutsche Bank, which stresses that legislative packages such as BRRD, CRD, CRR and EMIR will tackle sufficiently interconnectedness and contagion risk between financial entities. It also questions whether there are any 'material financial stability benefits that would arise from the implementation of [additional] structural reform proposals. $^{37}$
The International Capital Market Association (ICMA) is a pan-European organization representing a broad range of capital market interests such as global investment banks, smaller regional banks, asset managers, exchanges, law firms, and other professional advisers. Its position warns about overlap among the various regulatory initiatives at the EU level and concludes that 'any final proposals which do emerge may not necessarily all fit neatly together in terms - either with respect to their content and/or their timing' $\left(\mathrm{ICMA}^{38}\right.$, p. 2). The association also highlights the interrelated financial regulatory reforms under way in the EU, such as 'improvements to bank capital and liquidity $(\mathrm{CRR} / \mathrm{D})$ and to the resolvability of banks which do nevertheless run into difficulties (RRD); alongside improved rules for trading (MiFIR/D, SSR and MAR/D); and new requirements for clearing (EMIR) and settlement (CSDR). Other measures further improve investor protection (PRIPS), whilst the buy side of the industry must also come to terms with its new regulations (AIFMD and UCITS)' $\left(\mathrm{ICMA}^{38}\right.$, p. 4).

Furthermore, The EACB emphasizes that banks have undergone significant behavioral adaptations because of the ongoing reforms and due to the demands of their shareholders and clients. Thus, it concludes that 'it is questionable if a general mandatory separation for all credit institutions will bring any added value. ${ }^{39}$ The association stresses that the problems of shortages of liquidity and supervision identified during the crisis are already being addressed by the CRDIV/CRR package, with its higher capital and liquidity requirements, more risksensitive approach, and new stringent governance and remuneration rules; the BRRD; the upcoming DGS Directive; and the CSD Regulation, which will change the business models of clearing houses. The association underscores the cumulative effect of BRRD, MiFID II, UCITS V, EMIR, AML and the Basic Payment Account Package - all introducing more stringent requirements. Especially regarding the BRRD, under certain conditions, the 
resolution authority has the power to require an institution to separate its activities at the stage of preventative powers or at the resolution stage. ${ }^{39}$ In a similar vein, the only organization from the new member states which filed a stakeholder position, the Czech Banking Association, stresses that the too-big-to-fail issue has already been addressed by quite a few other initiatives at the global or European level such as SIFI capital surcharges (G-SIFIs, D-SIFIs and so on ), bail-in tools, recovery and resolution planning. ${ }^{40}$ The association warns that streamlining European banks models through mandatory separation would decrease diversity and, ultimately, may negatively affect financial stability. ${ }^{41}$

\section{CONCLUSION}

Our analysis of 47 stakeholder consultation positions on European banking structural reform confirms that consumer organizations are the main proponents of introducing a ban on proprietary trading and enforcing structural separation of banks' deposit-taking and investment activities. The US and UK were pacesetter in this policy area, putting forward proposals such as the Volcker Rule in 2010 and Vickers Report in 2011. By contrast, the common EU approach to banking structural reform has developed more slowly than similar national initiatives in individual member states such as the UK, Germany, and France. The analysis shows that the majority of European banks and financial services associations are opposed to further banking structural reforms at the EU level. We also find evidence that banks domiciled in jurisdictions that have passed reforms prefer those over EU alternatives and large internationalized banks are most opposed to further EU banking structural reforms.

\section{ACKNOWLEDGEMENTS}

The authors are very grateful to the organizers of and participants in several conferences and workshops which allowed us to develop our argument: 'National versus Supranational
Banking Supervision' at the ECPR Joint Sessions of Workshops in Salamanca, Spain in 2014; NIG annual conference in Delft, the Netherlands in 2014; workshop on 'National versus Supranational Banking Regulation after the Crisis: Dilemmas for States' in Denver, USA in 2015. They would like to thank Rachel Epstein for her invaluable feedback and encouragement.

\section{REFERENCES AND NOTES}

1 See Germain, R. (2012) Governing global finance and banking. Review of International Political Economy 19(4): 530-535.

2 Ferran, E., Moloney, N., Hill, J.G. and Coffee Jr, J.C. (2012) The Regulatory Aftermath of the Global Financial Crisis. Cambridge, UK: Cambridge University Press. Mügge, D. (2014) Europe's regulatory role in post-crisis global finance. Journal of European Public Policy 21(3): 316-326.

3 Radaelli, C. and DeFrancesco, F. (2007) Regulatory Quality in Europe, Concepts, Measures, and Policy Processes. Manchester, UK: Manchester University Press. Meuwese, A.C.M. (2008) Impact Assessment in EU Lawmaking. The Hague, The Netherlands: Kluwer Law International. Alemanno, A. and Meuwese, A.C.M. (2013) What role for impact assessment in non-legislative rule-making? European Law Journal 19(1): 76-92.

4 See Moschella, M. and Tsingou, E. (eds.) (2013) Great Expectations, Slow Transformations. Incremental Change in Postcrisis Regulation. Colchester, UK: ECPR Press. European Commission (2013b) Capital Requirements - CRD IV/ CRR - Frequently Asked Questions. MEMO/13/690, http://europa.eu/rapid/press-release_MEMO-13-690_en .htm, accessed 12 March 2015. Quaglia, L. (2014) The sources of European Union influence in international financial regulatory fora. Journal of European Public Policy 21(3): 327-345.

5 See Hennessy, A. (2014) Redesigning financial supervision in the European union (2009-2013). Journal of European Public Policy 21(2): 151-168. Howarth, D. and Quaglia, L. (2013) Banking Union as Holy Grail: Rebuilding the single market in financial services, stabilizing Europe's banks and 'completing' economic and monetary union. Journal of Common Market Studies 51(Annual Review): 103-123. Howarth, D. and Quaglia, L. (2014) The steep road to European Banking Union: Constructing the single resolution mechanism. Journal of Common Market Studies 52(Annual Review): 125-140. See Epstein, R.A. and Rhodes, M. (2014) International in Life, National in Death? Banking Nationalism on the Road to Banking Union. Berlin, Germany: Freie Universität Berlin. KFG The Transformative Power of Europe Working Paper no. 61, December.

6 See Robinson, D. (2014) Frans timmermans promises to slash EU red tape. Financial Times 7 October.

7 See Epstein, R.A. and Rhodes, M. This volume.

8 On the influence of financial industry lobbying see: Pagliari, S. and Young, K. (2014) Leveraged interests: Financial 
industry power and the role of private sector coalitions. Review of International Political Economy 21(3): 575-610. Young, K. (2014) Losing abroad but winning at home: European financial industry groups in global financial governance since the crisis. Journal of European Public Policy 21(3): 367-388.

9 FDIC (2015) Selected sections of the Dodd-Frank wall street reform and consumer protection Act, https://www .fdic.gov/regulations/reform/dfa_selections.html, accessed 4 April 2015.

10 FTI Consulting (2014) Volcker, Vickers, Liikanen: Structural reforms of the banking sector - Quo Vadit Europe? http:// www.fticonsulting.com/insights/white-papers/volckervickers-liikanen-structural-reforms-of-the-banking-sectorquo-vadit-europe.

11 Financial Stability Board (2014) Structural Banking Reforms. Cross-border consistencies and global financial stability implications. Report to G20 Leaders for the November 2014 Summit, 27 October, p. 1, Basel.

12 European Commission (2014) Proposal on banking structural reform, http://ec.europa.eu/finance/bank/structuralreform/index_en.htm, accessed 12 March 2015.

13 Liikanen, E. et al. (2012) Report of the High-level Expert Group on reforming the structure of the EU banking sector, http://ec.europa.eu/internal_market/bank/docs/high-level _expert_group/report_en.pdf.

14 See Young article, this volume; Macartney and Jones article, this volume; Germain article, this volume.

15 Data about bank size in terms of total assets taken from 'The Banker' database, http://www.thebankerdatabase.com/ index.cfm?fuseaction $=$ top 50. default\&page $=1$.

16 PricewaterhouseCoopers (2014) Impact of Bank Structural Reforms in Europe. Report for AFME, November, London.

17 Barker, A. (2015) EU reforms to break up big banks at risk. Financial Times 29 January.

18 Barker, A. (2014) Banking groups push Brussels to ditch overhaul of big lenders. Financial Times 23 November.

19 European Commission (2013) Consultation on reforming the structure of the EU banking sector, http://ec.europa.eu/ finance/bank/structural-reform/index_en.htm, accessed 12 March 2015.

20 Chalmers, A.W. (2014) In over their heads: Public consultation, administrative capacity and legislative duration in the European Union. European Union Politics 15(4): 595-613. Rasmussen, A. and Toshkov, D. (2013) The effect of stakeholder involvement on legislative duration: Consultation of external actors and legislative duration in the European Union' European Union Politics 14(3): 366-387. Young, K.L. (2013) Financial industry groups' adaptation to the post-crisis regulatory environment: Changing approaches to the policy cycle. Regulation \& Governance 7(4): 460-480.

21 Quittkat, C. (2011) The European commission's online consultations: A success story. Journal of Common Market Studies 49(3): 653-674

22 See Mayring, P. (2000) Qualitative content analysis. Forum: Qualitative Social Research 1(2): 1-10.

23 See Hall, P.A. and Taylor, R. (1996) Political science and the three new institutionalisms. Political Studies XLIV: 936-957. Thelen, K. (1999) Historical institutionalism in comparative politics. Annual Reviews of Political Science 2: 369-404.
24 Bank of England - Prudential Regulation Authority (2014) The implementation of ring-fencing: Consultation on legal structure, governance and the continuity of services and facilities - CP19/14, http://www.bankofengland.co.uk/ pra/Pages/publications/cp/2014/cp1914.aspx, accessed 12 March 2015.

25 The Independent Commission on Banking (2011) Final report recommendations, http://webarchive.nationalarchives.gov.uk/20131003105424/https:/hmt-sanctions.s3. amazonaws.com/ICB\%20final\%20report/ICB\%2520Final\% 2520Report\%5B1\%5D.pdf, accessed 10 October 2013.

26 German and French banking structural reform report.

27 Spendzharova, A. (2014) Banking union under construction: The impact of foreign ownership and domestic bank internationalization on European union member states' regulatory preferences in banking supervision. Review of International Political Economy 21(4): 949-979.

28 European Association of Co-operative Banks (2013) EACB response to the Commission consultation on Reforming the structure of EU banking sector, p. 7, http://ec.europa.eu/ internal_market/consultations/2013/banking-structuralreform/index_en.htm.

29 Association for Bank Customer Rights in Sweden (2013) Reply to Consultation on Reforming the structure of the EU banking sector, p. 2, http://ec.europa.eu/internal_market/consultations/2013/banking-structural-reform/ index_en.htm.

30 Financial Services User Group's (FSUG) (2013) Reply to the consultation on Reforming the structure of the EU banking sector, http://ec.europa.eu/internal_market/consultations/ 2013/banking-structural-reform/index_en.htm.

31 La Caixa Group (2013) Consultation by the Commission on the Structural Reform of the Banking Sector. Response by 'la Caixa' Group, p. 2, http://ec.europa.eu/internal_market/ consultations/2013/banking-structural-reform/index_en.htm.

32 Crédit Agricole (2013) Response of the Crédit agricole group to the European commission consultation on reforming the structure of the EU banking sector, p. 19, http://ec europa.eu/internal_market/consultations/2013/bankingstructural-reform/index_en.htm.

33 Danske Bank (2013) Response to the consultation by the European Commission on Reforming the structure of the EU banking sector, p. 3, http://ec.europa.eu/internal_market/consultations/2013/banking-structural-reform/ index_en.htm.

34 Royal Bank of Scotland (RBS) (2013) European commission consultation on reforming the structure of the EU banking sector. Response by RBS Group, p. 2, http://ec.europa.eu/ internal_market/consultations/2013/banking-structuralreform/index_en.htm.

35 German Banking Industry Committee (2013) Opinion to Directorate General Internal Market and Services: Consultation Paper on Reforming the Structure of the EU Banking Sector.

36 European Commission (2014) Proposal on banking structural reform, http://ec.europa.eu/internal_market/consultations/2013/banking-structural-reform/index_en.htm.

37 Deutsche Bank (2013) Response to the European Commission Consultation on Reforming the Structure of the EU Banking Sector, p. 2, http://ec.europa.eu/internal_market/consultations/2013/banking-structural-reform/index_en.htm. 
38 International Capital Markets Association (2013) Response to the European commission consultation on reforming the structure of the EU banking sector, http://ec.europa.eu/ internal_market/consultations/2013/banking-structuralreform/index_en.htm.

39 European Association of Cooperative Banks (2013) Response to the European Commission Consultation on Reforming the Structure of the EU Banking Sector, p. 4, http://ec.europa.eu/internal_market/consultations/2013/ banking-structural-reform/index_en.htm.
40 Czech Banking Association (2013) Response to the European Commission Consultation on Reforming the Structure of the EU Banking Sector, p. 3, http://ec.europa.eu/ internal_market/consultations/2013/banking-structuralreform/index_en.htm.

41 On the diversity of bank models see also: Bronk, R. and Jacoby, W. (2013) Avoiding monocultures in the European Union: The case for the mutual recognition of difference in conditions of uncertainty. LSE 'Europe in Question' Discussion Paper Series, Paper No. 67/2013, London. 